\section{Preparing Special Education Teachers to Affirm LGBTQ+ Students and Themselves}

\author{
AUTHOR \\ Bryan E. Cichy-Parker
}

\section{Journal of Special}

Education Preparation

1(2), 24-35

(C) 2021 Cichy-Parker

Licensed with CC-BY-NC-ND 4.0 License

DOI: 10.33043/JOSEP.1.2.24-35

openjournals.bsu.edu/JOSEP

\section{ABSTRACT}

Within their work, special education teachers are tasked with being knowledgeable on a wide array of human diversity. Although attitudes have been changing rapidly toward sexual and gender minorities in recent years, data from the Gay, Lesbian and Straight Education Network's (GLSEN) most recent National School Climate Survey indicated that $52.4 \%$ of students reported hearing homophobic remarks and $66.7 \%$ of students reported hearing negative remarks about gender expression from their teachers or other school staff (Kosciw et al., 2020). This article identifies three areas in which special education teacher educators can interact with their teacher candidates to support learning about the LGBTQ+ community and equip them to work with their future students who identify as a sexual or gender minority. Techniques included address the use of qualitative assessment through discussion and journaling; building cultural empathy via affective learning, perspective taking, acceptance of cultural differences, awareness, and appropriate responding via an understanding of intersectionality and intention versus impact.

\section{KEYWORDS}

Cultural empathy, LGBTQ+, special education, teacher preparation

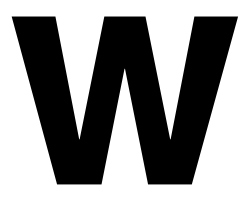
ithin their work, special education teachers are tasked with being knowledgeable on an incredible array of human diversity. Not only do they work with people of varying cognitive levels and academic skills, but special education teachers work to meet the needs of people with differing physical attributes, varied modes and methods of communication, and widely ranging social and emotional regulation skills. Despite this commitment to the expansive diversity of human life, some pre-service teachers either draw the line at or allow themselves to be unprepared to deal with a sliver of human diversity that has begun receiving increasing attention in recent decades: sexual orientation and gender identity. These areas of the human experience are a new frontier in the United States among educators of all types and levels, with $60 \%$ of LGBTQ+ youth reporting that they have experienced some discriminatory policies or practices at school (Kosciw et al., 2020). As educators of teacher candidates destined to become special education teachers, the field must support familiarizing pre-service teachers with this topic or new teachers will leave their preparation programs unprepared to help students with disabilities who identify as part of the LGBTQ $+{ }^{1}$ community.

\section{Context of the Problem}

Prior to 1999 there was little known to the field of education about the experiences of LGBTQ+ students and educators. In the fall of that year, however, the Gay Lesbian Straight Education Network (GLSEN) began biennial surveys of school climate. Data

\footnotetext{
${ }^{1}$ While there exist many variations of the umbrella term for the community of people who identify as gender and sexual minorities, the Caucus of LGBTQ + Special Educators of the Council for Exceptional Children currently uses the acronym used here in their name, and that designation will be used throughout this article.
} 
from their most recent National School Climate Survey, completed in 2019, reported that " $52.4 \%$ of students reported hearing homophobic remarks from their teachers or other school staff [emphasis added], and $66.7 \%$ of students reported hearing negative remarks about gender expression from teachers or other school staff" (Kosciw et al., 2020, p. xix). While one would hope that these teachers and school staff would not represent all of the adults that these students would interact with in a day, "less than one-fifth of LGBTQ students $(13.7 \%)$ reported that school staff intervened most of the time or always when overhearing homophobic remarks at school, and less than one-tenth of LGBTQ students $(9.0 \%)$ reported that school staff intervened most of the time or always when overhearing negative remarks about gender expression" (Kosciw et al., 2020, p. xix).

Although attitudes have been changing rapidly toward sexual minorities in recent years, Dee and Henkin (2002) found that preservice teachers who were seeking licensure in special education expressed significantly lower levels of comfort with cultural differences, i.e., "deviations from White, middle-class, monolingual backgrounds" (p. 25), than preservice teachers who intended to specialize in elementary education. They hypothesized that these students might downplay the need for cultural competence when working with students with special needs because of a lack of exposure to classrooms that included students from a wide range of backgrounds. Regardless of the reason, Wyatt et al. (2008) found that "teacher preparation is needed on all sexuality issues, particularly issues specific to homosexuality and sexual minority students to better ensure a greater appreciation for the challenges that lesbian, gay, and bisexual youth face" (p. 181).

These data illustrate the need for special education teachers to develop these important cross-cultural skills. An important finding in the 2019 National
Survey on LGBTQ Youth Mental Health, administered by The Trevor Project, underscores the urgency needed for these improvements in special education teacher preparation to occur. With over 34,000 respondents, almost $40 \%$ of LGTBQ+ youth and more than 50\% of transgender and non-binary youth "seriously considered attempting suicide in the past twelve months" (p. 1). In addition, LGBTQ+ students who had been victims of harassment in their schools reported higher levels of missing school, had lower grade point averages, and were nearly twice as likely to report that they did not plan to seek any postsecondary education or training (Kosciw et al., 2020). All indications would suggest that students with disabilities who identify as LGBTQ+ suffer in these same ways, but these risks may be compounded based on their pre-existing needs related to their disabilities.

Special education has long been trying to reckon with systems that lack the ability to deal adequately with diversity. The disproportionate representation of African American students (e.g., Cruz \& Rodl, 2018) and the unpacking of language differences from language disability among students from diverse language backgrounds (e.g., Roseberry-McKibbin, 2021) are both ways in which our institutionalized systems struggle to match our evolving world. LGBTQ+ students represent another group which has been minoritized in our field and to which special education systems need to attend.

Gorski et al. (2013) reviewed syllabi from 41 teacher education multicultural education courses from across the United States. They found that LGBTQ+ concerns were largely not included in the syllabi in their sample, and, when they were, they were done so in a way that was decontextualized from schools and the work of educators. Although their study was completed almost a decade ago, teacher educators of today must not assume that pre-service teachers will get what they need through informal methods or from outside the teacher education coursework. Instead, teacher educators must provide opportunities for pre-service teachers to learn about sexual and gender minorities in the modern contexts of schools and society.

To that end, I have identified three areas in which special education teacher educators can interact with their students to support this learning and empower them to work with their own students who identify as part of the LGBTQ+ community: qualitative assessment, empathy building, and appropriate responding.

\section{Qualitative Assessment}

Vygotsky (1978) introduced to the fields of psychology and education the concept of the zone of proximal development. This concept guides educators to determine that which is the next thing necessary for a student to learn. If a learner is instructed at a level beyond their capacity, no learning occurs; and if a learner is instructed far below their current knowledge, the learner becomes bored, and no learning occurs. In a similar way, since their introduction, McLeskey et al.'s (2017a), high leverage practices in the field of special education have highlighted the need for high quality assessment to precede instruction. These practices, while ostensibly focused on the job of educating school-aged children with disabilities, serve as useful in our job of preparing high quality educators as well. High Leverage Practice \#4 asks us to "use multiple sources of information to develop a comprehensive understanding of a student's strengths and needs" (McLeskey et al., 2017b, p. 2). The strategies that I use in my courses to assess student knowledge and readiness to learn about LGBTQ+ issues include mainly discussion and journaling, with several scaffolds built into my course to support these data-gathering tools. Determining the students' zones of 
proximal development helps the instructor tailor the flow of information in the classroom to remain within the bounds of what students already know and what they are prepared to learn.

\section{Discussion}

I use a developmental approach to classroom discussions. While some preservice teachers have experience debating controversial topics in front of large groups, many others do not possess that skill. Others suffer from such anxiety that they are unable to engage with the topics at the same time they are managing their emotional responses. To specifically support those who struggle with classroom participation, I use check-in questions (Wong \& Wong, 2018) that move from surface-level to deeper significance over the course of the semester, with the express goal of simply letting the shyer students hear their own voice in the room in front of other students. The first day of class, for instance, I might ask them to state something as inconsequential as their favorite flavor of ice cream. On other occasions, I offer a variety of check-in questions at various levels of challenge, allowing each student to choose the one they feel comfortable speaking to in front of the group. Using this method of assessment, I can determine individual and group needs as they pertain to the topics of the day which may include race, class, sex, gender and/or sexuality, or the intersections of any of those constructs.

Questions that might be appropriate for a check-in on the topic of LGBTQ+ issues, moving from less challenging to more challenging would be: (a) At what age is it appropriate to ask a child if they have any girlfriends or boyfriends at school?; (b) Can you recall the circumstances of when you first learned that homosexuality exists? What can you share with us about that?; and (c) What aspects of your high school experience might have been different for someone who had a minoritized sexual orienta-

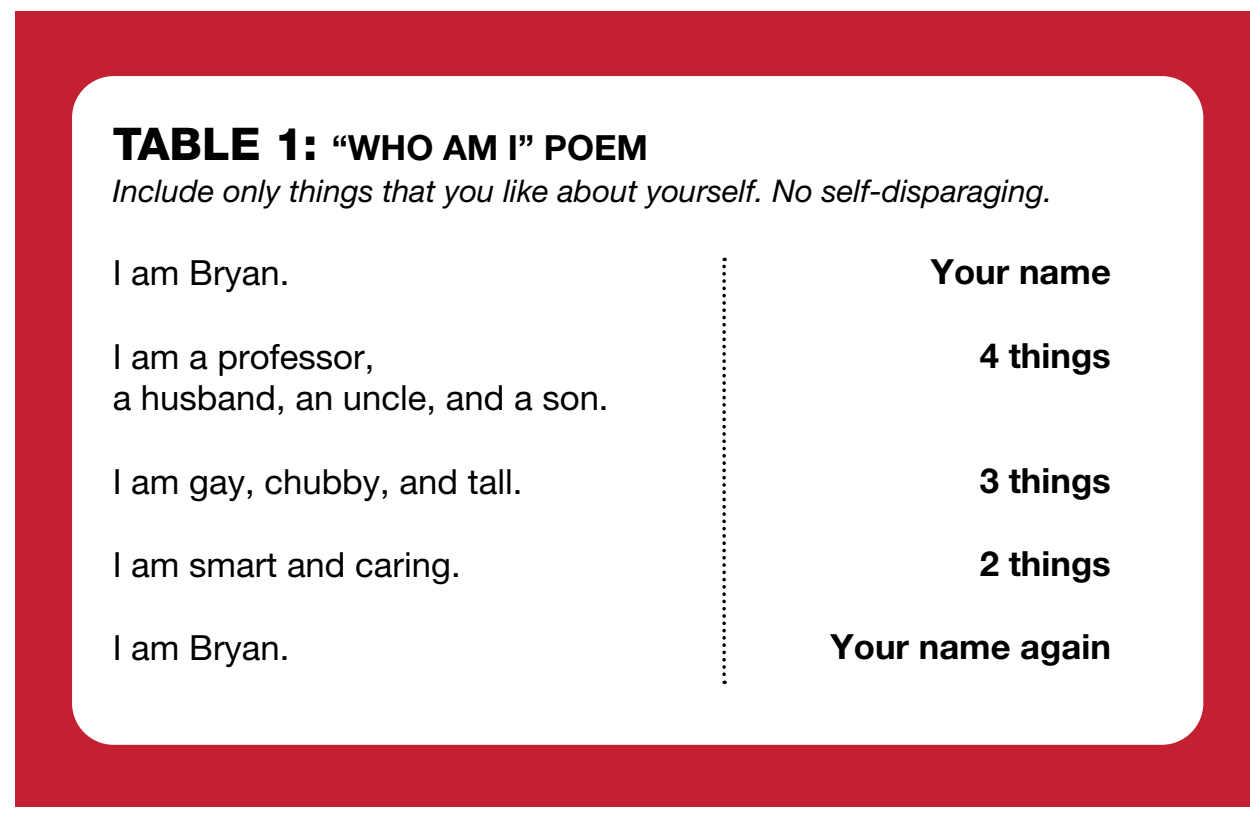

\section{TABLE 2:}

\section{STANDARD GROUND RULES}

1 Listen to understand, not to respond

2 Ask clarifying questions

3 Assume positive intention, unless proven otherwise

4 Everyone owns their own stories

5 Stay engaged in the main conversation

tion or gender identity? Or, for someone who identifies as part of the LGBTQ+ community, In what ways did your high school experience differ from someone who had a mainstream sexual orientation or gender identity?

A relatively low stakes warm up task that I use to support student success in discussions is the Who Am I? poem (see Table 1) or the Where I'm From poem (Christensen, 1997). The Who Am I poem asks the students to create a five-line poem using a strict format that is based on their self-image. Because it is very prescribed, I have noticed that students risk less than if they had to write an original poem on their own and therefore are more comfortable in participating. The Where I'm From poem works in a similar way but has the additional benefit of inviting a student's cultural environment into the classroom (see Christensen, 1997 for a full treatment of how to use this strategy). Students are encouraged to start with the line, "I am from" followed by a description of some items found inside their home, maybe something they could find in their yard or in their neighborhood, and then to describe images or memories they have associated with relatives, celebrations, or foods. Based on the level of self-disclosure in which each person engages, I, along with their classmates, develop an understanding of their comfort with speaking and with the content we will be covering.

As a prerequisite to asking the students to engage in deeper self-disclosure, I do an activity in which we set ground rules for the course (Chan \& Treacy, 1996). I randomly divide the students into groups of four or five students and ask them to brainstorm several ideas about what they would need in our classroom environment to be able to talk about difficult issues in front of the whole group. After giving them time to confer, I move 
from group to group, asking a different student to respond each time with one of the ideas that they generated. As they speak, I type their responses into concept mapping software that is mirrored on an overhead screen, continuing in this way until all items have been shared. At that point I start grouping their comments into similar ideas until I am left with three to five positively stated rules. These rules are then prominently posted in the classroom and restated and positively reinforced in all course sessions from that point forward. I do tell the students that I maintain the right to add or subtract as I need to. There are some rules that I know need to be represented, and I will steer the end result to making sure that those ground rules appear in our final set. See Table 2 for the standard set of ground rules.

\section{Journaling}

Journaling is another tool to gather information on students' knowledge and readiness to learn. Fisher and Frey (2004) compiled a list of strategies used by teachers to support adolescent literacy, and among those strategies was exit tickets. In the middle school environment, exit tickets may take many different forms, but generally are a way for teachers to get feedback from students on their learning at the end of each class period. Typical exit tickets for that age group might ask, "What is one thing you learned today?" or "Of the three types of vertebrates we studied today, which was your favorite and why?" They are quick and can provide the teacher with information on what was learned by the students. Instead of an exit ticket, I require my students in the multicultural course that I teach to complete journal entries at the end of each session.

Prior to the pandemic, I printed journal templates onto card stock with the dates of each class session and spaces for the student's journal entry and a short response from me. In order to accom-

\section{TABLE 3: RUBRIC FOR JOURNAL ENTRIES}

Journal entries are not meant to be a long, fully developed treatment of overlapping and complex factors. I want journal entries to be thoughtful processing of the ideas I have put in front of you and a critique of those ideas compared to the ideas you brought into the course. Journal entries can be short and still powerful, just as they can be long and still lack engagement with important issues. A good starting point for any of the journal entries is to ask yourself these two questions: How did what we discussed today apply to my life as it was when I showed up here today and what does it mean for me moving forward?

\section{Level Description}

1 Unengaged

2 Non-Reflective

"Today's class was really interesting."

Superficial descriptive writing approach (fact reporting, vague impressions) without reflection or introspection

\section{Thoughtful Introspection}

Elaborated descriptive writing approach and impressions without reflection

4 Reflection

Movement beyond reporting or descriptive writing to reflecting (i.e., attempting to understand, question, or analyze the event)

5 Critical reflection

modate distance learning during the pandemic, however, I used a Google Doc template that each student copied to their own Google Drive and then shared with me. I added shortcuts to each of those documents into a folder and then had access to each student's journal remotely. As with the card stock, I would review their responses after each class and respond in some fashion. My responses are to positively reinforce their contributions, and often I would ask a probing question to encourage even deeper levels of thinking. Because the purpose of this activity is assessment, I also provided a rubric for students to help move them to higher levels of critique and self-reflection rather than reinforcing a simple restatement of the day's activities (see Table 3 for a copy of the rubric, based on Wald et al. (2012) as it appears in my syllabus).

Apart from the benefits of being able to use the journals as formative assessment, Acquah and Commins (2015) found that journals have an additional benefit. These authors found that students who engaged in journaling in multicultural education courses, "began to see themselves as cultural beings with lived experiences and multiple identities" (p. 802). The journals and the critical reflection with which they 
were created helped transform students' attitudes.

\section{Empathy Building}

The explicit development of empathy across cultures is a valuable tool for teacher educators to implement in the support of producing preservice teachers who can meet the needs of students with LGBTQ+ identities. Warren (2018) wrote that empathy serves two functions in cross-cultural and culturally responsive teaching. First, empathy is instructional in that it can help teacher candidates notice patterns in their worldviews that either support or work against culturally competent practice. Second, once empathy becomes a habituated practice, it can support self-discovery of cultural beliefs of students in their own classrooms. Cultural empathy is defined as, "composed of intellectual empathy, empathic emotions, and the communication of those two" (Ridley \& Lingle, 1996 as cited in Wang et al., 2003 , p. 230). Wang et al. (2003) further operationalized this definition into four factors: (a) feeling and expression, (b) perspective taking, (c) acceptance of cultural differences, and (d) awareness. I will briefly describe each of these factors below and explain the strategies I use in my course to develop them.

\section{Feeling and Expression}

Wang et al.'s (2003) first factor in the operationalization of cultural empathy is related to feelings and expression. More specifically, this factor highlights how people can comprehend, internally, the feelings of people who are the targets of discriminatory experiences and then communicate those feelings back externally with others. There are two sociological concepts that I use with students to help develop these abilities: The mythical norm and the looking glass self.

The mythical norm is a concept brought into my understanding of the world by Lorde (1984):
Somewhere, on the edge of consciousness, there is what I call a mythical norm, [emphasis in original] which each one of us within our hearts knows "that is not me." In america [sic], this norm is usually defined as white, thin, male, young, heterosexual, christian [sic], and financially secure. It is with this mythical norm that the trappings of power reside within this society. Those of us who stand outside that power often identify one way in which we are different, and we assume that to be the primary cause of all oppression, forgetting other distortions around difference, some of which we ourselves may be practising [sic]. (p. 116)

After some discussion, students relate to this term because they all have identified in their lives one way or another in which they do not fit the mythical norm, and they can identify how this perception of not living up to an unrealistic standard has affected them. Even students who do fit all the categories listed by Lorde can recognize, for the most part, that their lives have been different than for those who do not meet the mythical norm.

I present this excerpt of Lorde's work to students in an essay by Tatum (2000) that also informs students about a concept referred to as the looking glass self. The looking glass self (Cooley, 1902) is the conceptualization that individuals determine their own sense of self based on how others view them. These two terms become central to the students' development of feelings and expression, both of which support the growth of their cultural empathy, because the terms lead them to comprehend how they have allowed themselves to be defined by society. Through the strategies I previously described, discussion and journaling allow opportunities for students to try on these new feelings of being defined without their permission or knowledge, and they practice expressing these feelings in small groups, in front of the class, and in their journals. This knowledge appears to increase the amount of empathy they have for others who also are not able to meet the demands of being the mythical norm, specifically those who identify as LGBTQ+, and they have a basis for understanding how the looking glass self can begin to shape how one sees their role in society.

Tatum (2000) reported that in her experience white/straight/cis students, who experience privileges in their daily lives based on these identities, will generally not share these aspects of their identity in their Who Am I poems nor in other casual check-in or ice breaker activities, while people with marginalized identities often do. Sharing this revelation with the class after the poem check-in has been completed helps them understand how their socialization manifests itself unconsciously in their responses, especially when they reflect on their own race and whether they shared that or not.

\section{Perspective Taking}

Wang et al.'s (2003) operationalized definition of cultural empathy includes developing an individual's ability to take the perspective of people who experience marginalization or discrimination. I provide opportunities in my teacher preparation program for students to practice this skill using carefully scaffolded storytelling and personal experiences.

The first activity in my course that supports perspective taking is for each student to write a personal profile and then share their profile with a small group within the class. The profile assignment is introduced after I have shared a list of identity markers (see Figure 1) with the class that serves as an advance organizer. On the day that the profile assignment is due, the class period is devoted to sharing parts of their paper that they feel comfortable sharing 
FIGURE 1: Beginning List of Identity Markers

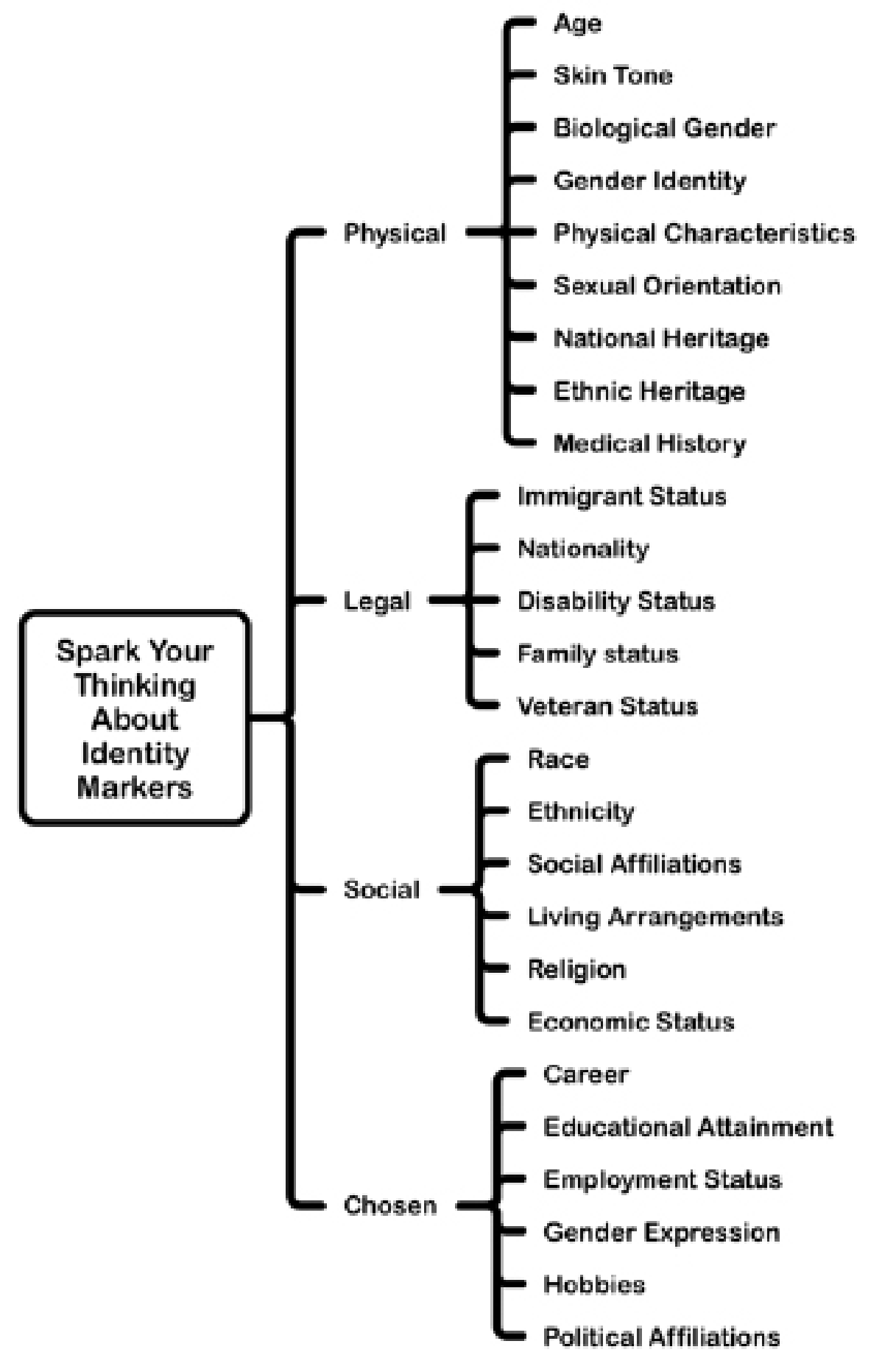

with others. Groups are designed so that each contains individuals from the widest gamut of diversity possible within those who have registered for the course. As homework after the first session of the semester, students complete a Google Forms survey that asks them about negative and positive experiences. In fact, I tell the students often that if they are not willing to work on the emotional baggage that they bring to the classroom, they are going to end up asking their students to carry it for them. I find that this experience helps them understand that even those who think they are "just normal" have had a journey that is unlike most others in the class. Understanding how another person has dealt with hurdles helps students grow in their ability to empathize with others and eventually to even feel some of the feelings that others have had.

The second strategy that I use to prepare preservice teachers to take the perspective of others is a panel discussion with people from the LGBTQ+ community. Each semester I organize a panel discussion that includes volunteer members of the class who identify as LGBTQ+ and members of the larger university and non-university community. Because I am gay, I likely have access to more individuals from the gay community to recruit as panelists than other educators might, but locating interested speakers should be made easier by partnering with LGBTQ+ community groups on campus or in the community. Many campuses and even K-12 schools now have Gay Straight Alliance groups that would provide contacts for panel participants. PFLAG, which originally stood for Parents and Friends of Lesbians and Gays, has over 400 local group chapters throughout the country and can be accessed at PFLAG.org. Also, the Gay Lesbian Straight Educator Network (GLSEN) maintains a list of local chapters at GLSEN.org. Finally, the LGBTQ+ Caucus of Special Educators can be utilized as a resource for finding people willing to work with your teacher candidates. They can be contacted at ceclgbtqpluscaucus.org.

I am careful to scaffold these experiences, using the assessment information that I gather, so that I can use the 
panel to meet students in their zones of proximal development and move the students forward in their ability to take the perspectives of members of the LGBTQ+ communities. In order to do that I ask the panelists to consider specific questions that I provide based on my assessment of the needs in the group. Typical questions that I ask of the panelists are similar to those listed here: (a) What name do you wish us to use?; (b) What pronouns do you use?; (c) Tell us a few things about yourself apart from your gender or sexuality.; (d) Please tell us more about your sexual or gender identity and how you came to realize that you were not the "mythical norm."; (e) Do you have a coming out story?; and (f) What bias have you experienced because of your gender or sexual identity? Follow up questions include: (g) Who were the 'helpers' in your life that made a difference for you?; (h) Have you ever had an openly LGBTQ+ teacher?; (i) Was school a safe or dangerous place? What could be done to make it safer?; (j) How does living with multiple aspects of identity (intersectionality) affect LGBTQ+ youth differently from their straight counterparts?; and $(\mathrm{k})$ What can a member of this class do if they want to support LGBTQ+ youth?

Through the personal profile and the LGBTQ+ Panel, preservice teachers are provided with multiple opportunities to take the perspectives of people in the LGBTQ+ community.

\section{Acceptance of \\ Cultural Differences}

The third factor in Wang et al.'s (2003) operationalized definition of cultural empathy is acceptance of cultural differences. This factor includes a focus on the understanding, acceptance, and valuing of the differences presented by people from outside the pre-service teacher's normal environment or from groups that are unknown to them. These differences include cultural traditions, life experienc-

\section{FIGURE 2: Intercultural Development Continuum}
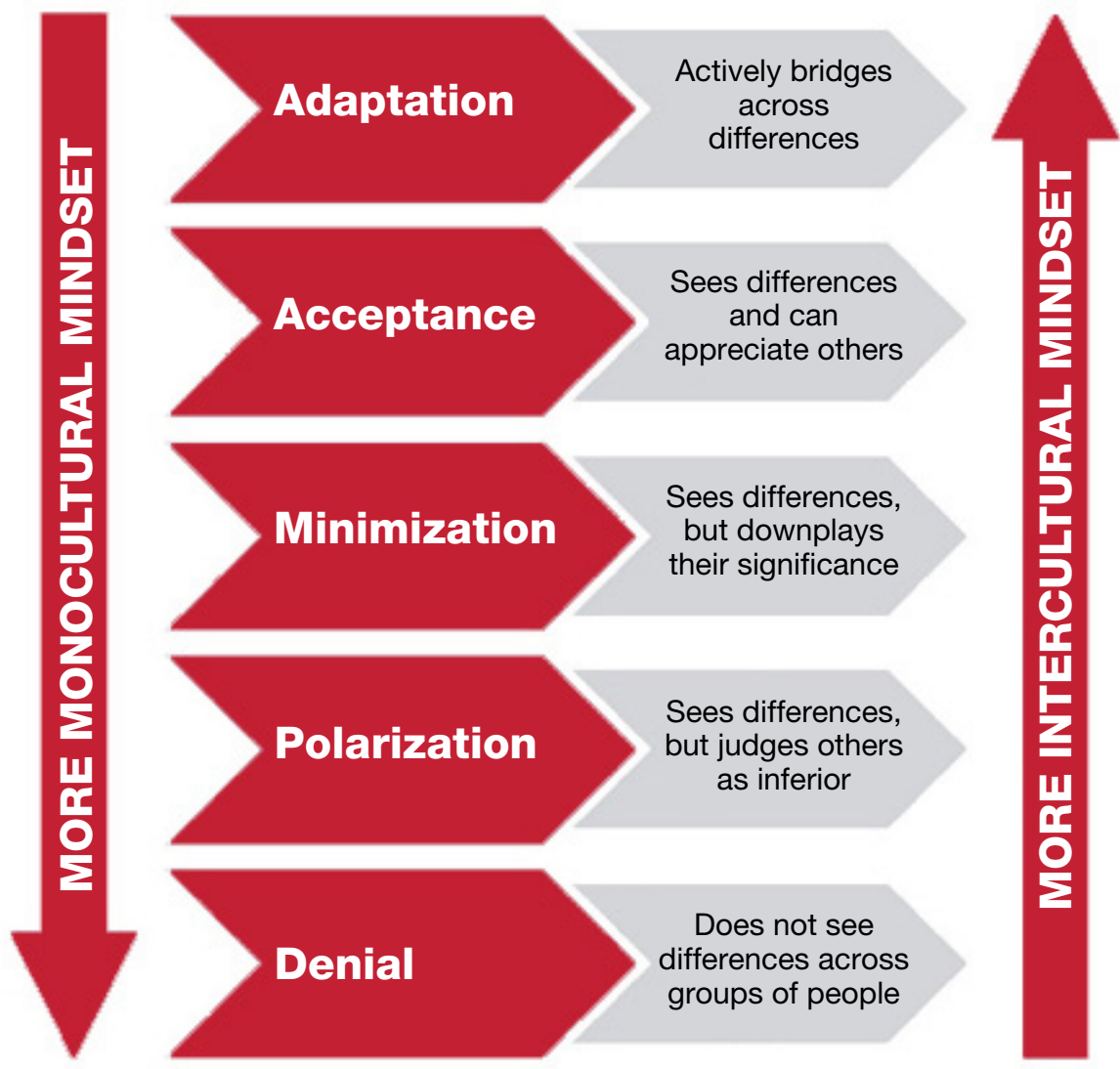

Note. Adapted from Hammer, M. (2012). The Intercultural Development Inventory: A new frontier in assessment and development of intercultural competence. In M. Vande Berg, R. M. Paige, \& K. H. Lou (Eds.), Student learning abroad (Ch. 5, pp. 115-136). Stylus Publishing.

es, and values of all those who are considered as separate from each individual.

The Intercultural Development Continuum (IDC; Hammer, 2012) is specifically designed to address students' knowledge and readiness to accept cultural differences. The IDC is a framework that describes a spectrum of attitudes towards intercultural understand that ranges from denial to adaptation (see Figure 2.) Students that avoid seeing the LGBTQ+ identities of people with whom they come into contact, or proclaim that all people are just human and that our differences do not matter, fall into the denial category of the continuum. Colorblindness as it applies to race would also fit into this area. As students grow in their understanding and appreciation of why knowing about difference matters, they move through the stages of polarization (seeing differences and judging the other as inferior), minimization (ignoring the aspects of LGBTQ+ people that they do not understand in an effort to just get along), and then acceptance (seeing difference as something worth learning about, yet, tending to interact with the other through curious tolerance). Polarization is the stage at which the Cultural Deficit Theory (Silverman, 2011) is most pronounced. The Cultural Deficit Theory is the belief by people who live in relative privilege that other people occupy the position they do in life because their culture is lacking in some fundamental way compared to the culture shared by those in power. The final point on the continuum is adaptation, at which individuals actively work to bridge differences and celebrate what each group brings to the other. 
The IDC framework helps me understand what the next developmental stage of my students' growth should look like. If, for instance, I am met with extreme resistance from an individual that learning about the LGBTQ+ experience is even necessary (denial), I will know that growth is happening when the student reports that they have learned something about sexual or gender differences and yet they still judge that characteristic to be inferior (polarization) to their own way of life. Although that might not feel like a win, moving from denial to polarization is growth in the right direction. Sharing this framework with the students helps them understand what I am looking for as they move through the stages as well. Teaching this framework helps students self-monitor their own learning and use their own cognitive strategies to reframe differences they see to shape their observations into progress on the continuum.

\section{Awareness}

The final factor in Wang et al.'s (2013) definition of cultural empathy is awareness. They define awareness as the "knowledge that one has about the experiences of people from racial or ethnic groups different from one's own" (p. 224). When developing cultural empathy about racial groups, for instance, much of the knowledge that is brought to the students is focused on providing historical perspective on the legal and social struggles that have occurred. The historical perspective is important for developing awareness of the LGBTQ+ community as well, but an additional area is also necessary: scientific understanding. The following sections summarize the content that preservice teachers need to learn to increase their awareness of these cultural groups. In delivering this content, I utilize typical teaching strategies of informal preassessment of current knowledge, careful planning of lessons with the use of graphic organizers, structured didactic instruction with many opportunities to respond, and summative assessment with feedback.

\section{- Developing Scientific Understand-}

ing. Teacher candidates who are resistant to the idea of encouraging or allowing the expression of diverse sexual and gender orientations often feel that way because of negative information that has been passed onto them and has been left unexamined. I have found that providing an opportunity for replacement thoughts and attitudes that are rooted in science and personal experience can remove some of the resistance shown. This resistance often occurs because of sincerely held religious beliefs, but even then, reframing some of these thoughts by providing deeper understanding of the context can support student growth. The specific myths that sometimes need clarification include: (a) being LGBTQ+ is unnatural, (b) it is a choice, and (c) it is a fad.

First, some students believe that being bisexual, lesbian, or gay is unnatural. All people have a sexuality (including asexual), and that it is a part of the human condition. Traditionally, American society has withheld privilege from those people who identify as different from the mythical norm of straight and cisgender, but LGBTQ+ people have always existed despite that. In fact, homosexuality and non-typical gender roles are common in nature and have been observed in many animal species including humans. Kamath et al. (2019) reported that samesex sexual behavior has been observed in over 1,500 species across all types of animals from "primates to sea stars." They suggested that sexual activity has not evolved exclusively for reproduction, but that it could have other purposes that have yet to be fully explored by science. Additionally, a person's gender identity is not determined by their sex organs, and even sex organs are not always binary. Feldman Witchel (2018) lists 24 conditions that result in ambiguous genitalia, and García-Acero et al. (2019) found that these occur once out of each approximately 4,500 births. Identifying as transgender occurs more frequently than the biological ambiguities do, with estimates at 390 adults per 100,000 or 1 in 256 people (Meerwijk \& Sevelius, 2017).

Second, some teacher candidates believe that identifying as part of the LGBTQ+ community is a choice. While there still exist areas of disagreement on whether people are born LGBTQ+ or become so later (nature v. nurture), there is evidence to support that choice is not involved. A survey of research on the causes for divergent sexual and gender identities by Bailey et al. (2016) demonstrated that many hypotheses have been suggested, such as hormones, genes, birth order, and even recruitment by other homosexuals; however none of these have been shown to be strong enough to garner support of a majority of reasonable scientists as the single factor. Yet, there may be some validity to one extent or another of all these hypotheses. I recommend sharing Bailey et al.'s (2016) work as a reading with preservice teachers as it is a comprehensive review of these theories. In the end, the only choice is to live in harmony with one's nature or to continually exert one's energy to fight against it.

Finally, some believe that having a minoritized sexual or gender identity is a fad that has arisen because of a liberal social environment. Although it is true that more people are identifying as trans than ever before, that is due in large part to there not having been a clear term for people who now identify as trans prior to the 1960s. Williams (2014) reported that the word only gained widespread use in the 1990s. There are records of trans individuals living in every society across history, but stories of their experiences are seldom those stories that are reproduced in traditional history courses in American schools The National Park 
Foundation/National Park Service (2016) compiled an excellent history of trans individuals in the United States' history.

- Providing Historical Perspective. As social scientists understand more about the ways in which cultural power is produced and reproduced in American society, they more deeply understand the ways in which erasure of a group's history contributes to their continued oppression, and special educators need to be sensitized to certain issues in LGBTQ+ history.

The fight for civil rights in the United States has followed a similar trajectory across diverse groups. Watershed moments in civil rights history provided a backdrop to structural change that provided advancements to people from all oppressed groups in different measures. The Brown v. Board of Education decision in 1954 was ostensibly about the inherent inequality of separate schools for Black and White Americans, but the decision, combined with the growth in population of the Baby Boomer generation, caused a shock to the Jim Crow-era systems of separate but equal and set the stage for integration where segregation had once been the rule. This decision started the change on how American society viewed racially segregated school settings and, over time, had an eventual impact on segregated settings in special education based on disability. The civil rights act of 1964 pushed those changes ahead by tying federal money to desegregation efforts. LGBTQ+ individuals were not specifically protected by the Civil Rights Act of 1964, but by 1969 they were poised to enter the fight as well.

The Stonewall Inn, formerly a gay bar in lower Manhattan, is considered the birthplace of the gay pride movement in the United States. Patrons at the Stonewall Inn, majority men, who might now be known as trans women (although the term was not in use then) and mostly people of color were accustomed to police raids and harassment. One of these raids took place at 1:20 a.m. on Saturday, June 28th, 1969, and rather than disperse, the patrons refused to be targets of the police and they fought back. This started a protest that escalated into a riot that lasted for three days. Allies and the LGBTQ+ community came from all over the city to make it known that they would no longer accept being targeted by the police. One year later, in June of 1970, the community returned to the Stonewall Inn to commemorate the uprising, and that gathering became the first pride celebration (Varga et al., 2019). Pride has been celebrated in June every year since in many cities in the United States and in many other countries around the world.

The victory was short-lived, however. On June 5th, 1981 the Center for Disease Control published a report describing a rare lung infection among a small group of gay men, all previously healthy, in Los Angeles (HIV.gov, 2018). This report was the official start of the AIDS crisis. AIDS stands for acquired immunodeficiency syndrome and is the name of the group of opportunistic infections that take over one's body when the human immunodeficiency virus (HIV) attacks the body and is not met with medical intervention. AIDS was a pandemic, not unlike our recent experiences with COVID-19, except that the early victims were generally gay men, and religious traditionalists wrote off these deaths as a just punishment for an unacceptable lifestyle. At the beginning of the crisis, there was no standard medical protocol for intervention, and funding for finding treatments was delayed because of anti-gay bias. People were scared and felt that a positive test for HIV was a death sentence. In fact, by 1995 when AIDS deaths hit their all-time yearly high, 319,849 people had died in the United States since the beginning of the crisis (amFAR, n.d.). Contrast that with the 300,000 deaths from COVID by the time the vaccine was first distributed
(Hearon, 2020). Today there still is no cure nor a vaccine for HIV/AIDS, but there are medical protocols that do work to fight its effects on one's body and ways to avoid contracting the virus even if one is exposed (Pre-Exposure Prophylaxis or PREP). A teacher candidate in my course this past year who was born in 2001 said that she had heard about AIDS before, but she, "had no idea that it was such a big deal."

Much of the attention of the LGBTQ+ community was spent dealing with the effects of HIV and AIDS, but legal systems in the 1980s and 1990s continued to be stacked against gay people. In 1993 Hawaii's supreme court offered a glimmer of hope when it ruled that it may be unconstitutional to ban same sex marriage, but, seeing a political opportunity, a conservative United States Congress quickly passed the Defense of Marriage Act, which determined that marriage was the union of one man and one woman. President Clinton signed that bill into law while also instituting a policy of "Don't Ask, Don't Tell" in the military. The policy barred harassment of closeted LGBTQ+ individuals in the military, which was good, but also barred those individuals who openly admitted to being part of the LGBTQ+ community from serving. During the period in which the Defense of Marriage Act was in effect, several states experimented with civil unions instead of marriage, but the legal axiom of Brown v. Board of Education, separate but equal is inherently unequal, held true, and the push for marriage equality continued.

Being gay was itself a crime in many parts of the United States until 2003. It was not until the Lawrence v. Texas case decided by the Supreme Court in June of 2003 that LGBTQ+ people were affirmed in their "right to private sexual intimacy with other adults" that heterosexuals had always had (Lambda Legal, n.d.). In another victory, under Obama's presiden- 
cy, the "Don't ask, Don't tell" policy was repealed in 2010 and LGBTQ+ individuals were allowed to serve their country in the military. In 2015, the Supreme Court decided in Obergefell v. Hodges that the 14th Amendment to the Constitution guaranteed the same rights of due process and equal protection to same-sex couples that were enjoyed by opposite-sex couples. This ruling overturned the Defense of Marriage Act and allowed LGBTQ+ people the right to marry and for spouses of any gender to be treated equally in the eyes of the law.

The issue of conversion therapy is still an open legal issue in some states. Conversion therapy is a largely discredited practice in which an individual is acted upon in order to change their sexual orientation or gender identity. The Trevor Project (n.d.) says that this practice may be known by other names such as "gender critical therapy," "reparative therapy," "ex-gay ministries," or SOCE/GICE, which stands for sexual orientation and gender identity change efforts. The American Academy of Child \& Adolescent Psychiatry published a position statement on the practice that it has no evidence to support its effectiveness and "should not be part of any behavior health treatment of children and adolescents" (2018, para. 4). So far twenty states also ban this practice because it can put children at even greater risk for depression and suicide (Sopelsa, 2020).

\section{Appropriate Responding}

While becoming an ally to any marginalized population takes years of listening and reflection to unlearn patterns that have been socialized into us by the dominant culture, there are a few concepts that can make it more likely that attempts at allyship will land as they are intended. Those three concepts are intersectionality, impact over intention, and recovering from mistakes.

Intersectionality. Crenshaw first presented the concept of intersectionality in 1989 as she explained how neither the pro-Black movement nor the feminist movement of the time adequately spoke to the lived experiences of Black women because they experienced oppression within both of those movements. The pro-Black movement did not deal with the issues of women adequately, and the feminist movement spoke more to the experiences of white women. Living in the intersection of these two movements required something more than what was available in either of the movements alone. This concept of intersectionality has been extended by other critical theorists to take on an idea of multiple identities (Sensoy \& DiAngelo, 2017) in that no individual is just one thing, but rather all people experience their lives through the lenses of their intersecting identities, with different identities taking on various levels of salience across environments. Special education teachers recognize that students with disabilities are people with their own preferences, interests, needs, and strengths, and it is important that they also recognize that the same concept applies to people who have an identity that aligns any individual with the LGBTQ+ community. Being trans, while a critically important identity marker for a person who is trans, is not a full identity on its own, but rather one aspect of a person's identity. Same sex attraction is part of an individual's experience in the world, but it does not represent everything that that person is. For example, when I was younger and shortly after I came out, my sister tried to play matchmaker for me and set me up on a date with another gay person she knew. The match was a failure, however, because she arranged a date for me that was based solely on the fact that we were both gay; she did not take into account any of the other aspects of our character or identities. Her attempt, while genuine and loving, failed because she forgot to look at the two of us as more than just our sexuality.

Impact over intention. Preservice special education teachers need to become familiar with the idea of intention versus impact when considering how to respond to difficult situations that involve students who identify as LGBTQ+. Although there are obviously some teachers who participate fully in creating hostile environments in schools, others may accidentally, through errors they commit or errors they leave uncorrected, offend their LGBTQ+ students without intending to. The intent of words or actions can play a role in how a student leaves such an interaction; therefore, teachers must deal with the impact of their statements and actions regardless of their intentions. For example, using the personal pronouns of trans and non-binary students that reflect their gender identities is an important part of creating space for those students to exist comfortably in schools. However, some well-intentioned guides may refer to these pronouns as a student's "preferred" pronouns which could impact these students negatively. Even though the intention of using the word preferred in this example is to communicate that they are thinking about the student's identity, using that particular word can have the impact of communicating that these pronouns are somehow imaginary, that they do not reflect reality, and are only being used as a kindness. In fact, the pronouns are not a preference and reflect the real gender identity that the student experiences. Teachers who are competent at interacting with LGBTQ+ students prioritize meeting the reality of the students, not the speaker's sense of being kind.

There exists the possibility of having our intentions overshadowed by the impact of our words, yet, there is also a danger of having our silence misinterpreted. As was mentioned in the context section earlier in this paper, only a small percentage of LGBTQ+ students trust that an ally will speak up consistently 


\section{ABOUT THE AUTHOR}

\section{Bryan Cichy-Parker}

Bryan Cichy-Parker, Ph.D., is an assistant professor and the coordinator of the graduate special education licensure program at Pacific University in Oregon. He is the current chair of the LGBTQ+ Caucus of Special Educators associated with the Council for Exceptional Children. His research interests focus on the provision of culturally responsive and culturally sustaining services for students with disabilities, especially as those services pertain to behavior management and academic learning. when overhearing anti-LGBTQ+ language. Silence tells students that no one is willing to stand up in their support, and it reinforces the lack of safety for them in those situations.

Recovering from mistakes. Mistakes will be made. Mistakes will be made both in the teaching of preservice teachers and by the teachers themselves once they have entered their classrooms. Every person's experience of their own identity is different, and there is no way to suggest to preservice teachers that there is a single correct intervention that will work with their students across individuals and across time. The error, however, lies in trying to never expose oneself to vulnerability and thus never portraying oneself as a person who cares.

\section{Being or Coming "Out"}

A question that has been repeatedly posed to me because of my vocal advocacy of LGBTQ+ rights in education is whether an individual should come out in their daily life as an educator or whether we as educators should suggest to our students with disabilities (and those who are typically developing as well) to do so while they are still in school. Advocates of LGBTQ+ rights strongly believe in the right for any individual to freely express their sexual orientation and gender identity as they see fit. Models of good mental health by Rogers (1959) suggest that people live their best lives when their real selves and their ideal selves are in alignment, and one way that many in the LGBTQ+ community live in that alignment is by allowing their identity as a member of the LGBTQ+ community to be known to others. Being out is a very personal decision, and each individual will have to live with the consequences of that decision.

Many people now enjoy the option of considering whether to be out because of others who have come before who either could not hide their identities or chose to no longer do so. The more of us that do live in an out manner, the more we normalize gender and sexual diversity for our fellow humans. If, however, an individual does decide to be out at school, there are two things that are prerequisite to doing so. First, confirm that the school district has an anti-discrimination, anti-harassment, or anti-bullying policy and that it has been read carefully. Second, the person must secure the blessing of their building administrator or direct supervisor. Both the policy and the support may be necessary for that person's continued ability to thrive in an environment that could become hostile. I have seen more and more students (both teacher candidates and K-12 students) over the years be able to live their truth in their schools.

\section{Conclusion}

Preservice special education teachers enter the field with many expectations placed upon them, and they bring a lot of expectations of themselves as well. In order to become the most effective teachers they can be, they must be able to provide a safe and welcoming environment to their students. If they are provided with the knowledge outlined in this paper, they will have improved the likelihood that they will be one of the teachers that makes a difference in the lives of students who identify as part of the LGBTQ+ community. Teacher training and induction programs thatpay attention to improving qualitative assessment, empathy building, developing scientific understanding, providing historical perspective, and giving options for appropriate responding will produce professionals that can meet the needs of LGBTQ+ students with disabilities in a culturally competent manner.

\section{References}

Acquah, E. O., \& Commins, N. L. (2015). Critical reflection as a key component in promoting pre-service teachers' awareness of cultural diversity. Reflective Practice, 16(6), 790-805. 
http://dx.doi.org/10.1080/14623943.2015.10 $\underline{95729}$

American Academy of Child \& Adolescent Psychiatry. (2018, February). Conversion therapy. https://www.aacap.org/AACAP/Policy Statements/2018/Conversion_Therapy.aspx

amFAR. (n.d.). HIV/AIDS: Snapshots of an epidemic. https://www.amfar.org/thirty-yearsof-hiv/aids-snapshots-of-an-epidemic/

Bailey, J. M., Vasey, P. L., Diamond, L. M., Breedlove, S. M., Vilain, E, \& Epprecht, M. (2016). Sexual orientation, controversy, and science. Psychological Science in the Public Interest, 17(2), 45-101. http://dx.doi. org/10.1177/1529100616637616

Chan, C. S., \& Treacy, M. J. (1996). Resistance in multicultural courses: Student, faculty, and classroom dynamics. American Behavioral Scientist, 40(2), 212-221. https://doi. org/10.1177/0002764296040002012

Christensen, L. (1997). Where I'm from: Inviting student lives into the classroom. Rethinking Schools, 12(2). Available at https://rethinkingschools.org/articles/where-i-m-from/

Cooley, C. H. (1902). Human nature and the social order. Scribner.

Crenshaw, K. (1989). Demarginalizing the intersection of race and sex: A Black feminist critique of antidiscrimination doctrine, feminist theory and antiracist politics. University of Chicago Legal Forum, 1989(8), 139-167.

Cruz, R. A., \& Rodl, J. E. (2018) An integrative synthesis of literature on disproportionality in special education. Journal of Special Education, 52(1), 50-63. https://doi. org/ $10.1177 / 0022466918758707$

Dee, J., \& Henkin, A. B. (2002). Assessing dispositions toward cultural diversity among preservice teachers. Urban Education, 37(1), 22-40. http://dx.doi.org/10.1177/0042085902371003

Feldman Witchel, S. (2018). Disorders of sex development. Best Practice \& Research Clinical Obstetrics \& Gynaecology, 48, 90-102. https://doi.org/10.1016/j.bpobgyn.2017.11.005

Fisher, D., \& Frey, N. (2004). Improving adolescent literacy: Strategies at work. Pearson/ Prentice Hall.

García-Acero, M., Moreno, O., Suárez, F., \& Rojas, A. (2019). Disorders of sexual development: Current status and progress in the diagnostic approach. Current Urology, 13(4), 169 178. http://dx.doi.org/10.1159/000499274

Gorski, P. C., Davis, S. N., \& Reiter, A. (2013). An examination of the (in)visibility of sexual orientation, heterosexism, homophobia, and other LGBTQ concerns in U.S. multicultural teacher education coursework. Journal of LGBT Youth, 10(3), 224-248. http://dx.doi.org/ $\underline{10.1080 / 19361653.2013 .798986}$

Hammer, M. (2012). The Intercultural Development Inventory: A new frontier in assessment and development of intercultural competence. In M. Vande Berg, R. M. Paige, \& K. H. Lou (Eds.), Student learning abroad (Ch. 5, pp. 115-136). Stylus Publishing.

Hearon, L. (2020, December 14). First COVID-19 vaccinations begin in U.S. Huffpost. https:// www.huffpost.com/entry/first-covid-19-pfiz- er-vaccine-us n 5fd732dcc5b6218b42ea 8472 HIV.gov. (2018). 37th Anniversary of the First Reported Cases of AIDS in the United States. https://www.hiv.gov/blog/37th-anniversary-first-reported-cases-aids-united-states

Kamath, A., Monk, J., Giglio, E., Lambert, M., $\&$ McDonough, C. (2019). Why is same-sex sexual behavior so common in animals? Scientific American. https://blogs.scientificamerican.com/observations/why-is-same-sex-sexual-behavior-so-common-in-animals

Kosciw, J. G., Clark, C. M., Truong, N. L., \& Zongrone, A. D. (2020). The 2019 National School Climate Survey: The experiences of lesbian, gay, bisexual, transgender, and queer youth in our nation's schools. Gay, Lesbian, Straight Education Network (GLSEN). https://www.glsen.org/research/2019-national-school-climate-survey

Lambda Legal. (n.d.). Lawrence v. Texas. https:// www.lambdalegal.org/in-court/cases/lawrence-v-texas

Lorde, A. (1984/2007). Age, race, class, and sex: Women redefining difference. In Sister outsider: Essays and speeches. Crossing Press. (Original paper delivered 1980).

McLeskey, J., Barringer, M-D., Billingsley, B., Brownell, M., Jackson, D., Kennedy, M., Lewis, T., Maheady, L., Rodriguez, J., Scheeler, M. C., Winn, J., \& Ziegler, D. (2017a, January). High-leverage practices in special education. Council for Exceptional Children \& CEEDAR Center.

McLeskey, J., Barringer, M-D., Billingsley, B., Brownell, M., Jackson, D., Kennedy, M., Lewis, T., Maheady, L., Rodriguez, J., Scheeler, M. C., Winn, J., \& Ziegler, D. (2017b, January). High-leverage practices in special education: Assessment: Research syntheses. Council for Exceptional Children \& CEEDAR Center. https://highleveragepractices.org/ sites/default/files/2020-10/Assessmentfinal. pdf

Meerwijk, E. L., \& Sevelius, J. M. (2017). Transgender population size in the United States: A meta-regression of population-based probability samples. American Journal of Public Health, 107(2), 1-8. http://dx.doi.org/10.2105/ AJPH.2016.303578

National Parks Foundation/National Parks Service. (2016). Chapter 10: Transgender history in the US and the places that matter. LGBTQ Heritage Theme Study. https://www.nps. gov/subjects/tellingallamericansstories/ lgbtqthemestudy.htm

Rogers, C. (1959). A theory of therapy, personality and interpersonal relationships as developed in the client-centered framework. In S. Koch (ed.), Psychology: A study of a science. Vol. 3: Formulations of the person and the social context. McGraw Hill.

Roseberry-McKibbin, C. (2021). Utilizing comprehensive preassessment procedures for differentiating language difference from language impairment in English learners. Communication Disorders Quarterly, 42(2), 93-99. https:// doi.org/10.1177/1525740119890314

Sensoy, O., \& DiAngelo, R. (2017). Is everyone really equal? An introduction to key concepts in social justice education. Teachers College Press.

Silverman, S. K. (2011). Cultural Deficit Perspective. In S. Goldstein, J. A. Naglieri (Eds.) Encyclopedia of Child Behavior and Development. Springer. https://doi.org/10.1007/978-0387-79061-9 750

Sopelsa, B. (2020, March 3). Virginia becomes 20 th state to ban conversion therapy for minors. NBC News. https://www.nbcnews.com/feature/nbc-out/virginia-becomes-20th-state-ban-conversion-therapy-minors-n1148421

Tatum, B. D. (2000). The complexity of identity: "Who am I?" In M. Adams, W. J. Blumenfeld, H.W. Hackman, X. Zuniga, \& M. L. Peters (Eds.), Readings for diversity and social justice: An anthology on racism, sexism, anti-semitism, heterosexism, classism and ableism (pp. 9-14). Routledge.

The Trevor Project. (n.d.). What is "conversion therapy?" https://www. thetrevorproject.org/get-involved/trevor-advocacy/50-bills-50-states/about-conversion-therapy/

The Trevor Project. (2019). National Survey on LGBTQ Youth Mental Health. https://www. thetrevorproject.org/survey-2019

Varga, B. A., Beck, T. A., \& Thornton, S. J. (2019). Celebrating Stonewall at 50: A culturally geographic approach to introducing LGBT themes. The Social Studies, 110(1), 33-42. https://doi.org/10.1080/00377996.2018.153 6643

Vygotsky, L. S. (1978). Mind in society: The development of higher psychological processes. Harvard University Press.

Wald, H. S., Borkan, J. M., Scott Taylor, J., Anthony, D., \& Reis, S. P. (2012). Fostering and evaluating reflective capacity in medical education: Developing the REFLECT rubric for assessing reflective writing. Academic Medicine, 87(1), 41-50. http://dx.doi.org/10.1097/ ACM.0b013e31823b55fa

Wang, Y, Davidson, M. M., Yakushko, O. F., Savoy, H B, Tan, J. A., \& Bleier, J. K. (2003). The scale of ethnocultural empathy: Development, validation, and reliability. Journal of Counseling Psychology, 50(2), 221-234.

Warren, C. A. (2018). Empathy, teacher dispositions, and preparation for culturally responsive pedagogy. Journal of Teacher Education, 69(2), 169-183. http://dx.doi. org/10.1177/0022487117712487

Williams, C. (2014). Transgender. TSQ: Transgender Studies Quarterly, 1(1-2), 232-234. http:// dx.doi.org/10.1215/23289252-2400136

Wong, H. K., \& Wong, R. T. (2018). The first days of school: How to be an effective teacher (5th ed). Harry K. Wong Publications.

Wyatt, T. J., Oswalt, S. B., White, C., \& Peterson, F. L. (2008). Are tomorrow's teachers ready to deal with diverse students? Teacher candidates' attitudes toward gay men and lesbians. Teacher Education Quarterly, 35(2), 171-185. https://www.jstor.org/stable/23479230 